Juhan Maiste

\title{
KADRIORG: THE SPIRIT OF BAROQUE AND THE WILL OF GENIUS. A PALACE ON THE EDGE OF THE THIRD ROME*
}

One of the first of the considerations that occurred to me was that there is very often less perfection in works composed of several portions, and carried out by the hands of various masters, than in those on which one individual alone has worked.

René Descartes ${ }^{1}$

Every painter paints with his blood.

Heinrich Wölfflin ${ }^{2}$

\section{EVERY ARTIST IS AN EGO}

Each work of art is unique and comes into being through spiritual enlightenment; this is a special feature that anyone writing on the arts must consider. Studying the arts, we are bound to a duality of issues and ap-

DOI: http://dx.doi.org/10.12697/BJAH.2013.6.06

Translation by Margus Tuvikene

* The essay is based on the following presentations by the author: Niccoló Michetti. Architect form the South in the North, held in the Dome church in Zagarolo, 21.10.2002; Classical versus Baroque. Italian architecture in the Baltic world, at the Academy of San Luca in Rome, 13.5.2007; Rome nowhere. Baroque in Estonia Before and After Niccoló Michetti, at the conference "Nicolo Michetti (1675(?)1758). Rooma-Tallinn-Peterburi", at the Kadriorg Art Museum, 4.6.-5.6.2009; Baroki kosmos ja Kadrioru park. Ideest vormini, at the conference "Kadriorg 295 - Barokne park tänapäeval”, Estonian Academy of Sciences, 21.9.2013.

1 René Descartes, “Discourse on Method”, The Philosophical Works of Descartes, vol. I, trans. by Elizabeth S. Haldene and G. R. T. Ross (London, New York, New Rochelle, Melbourne, Sydney: Cambridge University Press, 1986), 87.

2 Heinrich Wölfflin, Principles of Art History, The Problem of the Development of style in Later Art, trans. by Marie Donald Mackie Hottinger (New York: Courier Dover Publications, 1950), 1. 
proaches that are complex and often contradictory. On the one hand an artistic idea is foregrounded within an artwork while on the other, its inseparable formal aspect is brought forth. Without the first, the other ceases to be: without an idea, there is no reason for art to be born. Art is a middleman between its creator, nature and creation; with the help of a code, genius can assemble a representation of this relationship. The original form of a representation exists somewhere in an undefined entirety, in a place hidden from the ordinary sight, a place where artist can find a representation and give it shape and new strength - in this case the transcendental connection to the world of ideas (eidos) is as important as ties that people have with other people and with things. Artefacts differ from facts of life not in their aesthetic communication - however, this can be the case as well - but in the explosive energy that has been theorised by the likes of Leonardo and Lotman. Also, artefacts do not differ in their openness but rather in the closedness that they always inherit from their creator. Art borrows its themes from reality and replays them through mimesis, offering new ideas as the criteria and source of truth; within the new ideas mental hypostases are written that characterise cognitive perception.

So there are two distinct paths to understand an artwork: the first leads us towards the physical, the other towards the metaphysical. As heirs to a world-view that is based on the Enlightenment and the ratio, we carry within a conviction that analytic approach and cause-effect relationships predominate in the construction of belief systems, something that Occidental thought has taken for granted both for art history and for aesthetics. Yet these relationships only preliminarily hold sway with artworks because they represent a singular mental phenomenon.

Up to recent times methods passing over from the linguistic philosophy have prevailed in the literature on arts. Facing the subject-object problem, these methods give preference to the measurable and the tangible, thereby making creative thought graspable through the chosen approach and rhetoric but leaving the spiritual gates unopened for those who are critical - a choice that already Dante and Marsilio Ficino hinted at. Artefacts in a system function not unlike "nano-particles": they bind colour, form, and space, they arrange icons within a semiotic structure, determining the existence of an artwork as "a sign, or representamen, [...] something which stands to somebody for something in some re- 
spect or capacity. ${ }^{1 / 3}$ The subject of history of art often lies in the fields of iconology and semiotics, borrowing its method from natural sciences where "the relation between sign and object [...] is real and physical, which gives the sign the status of evidence for its object", hence there is "icon: in which that relation is based on resemblance; and symbol based on convention." ${ }^{4}$

Similarly to natural sciences history of art also divides its subject matter into parts - species and subspecies, families and styles; choices are made based on this classification that give Clio (the fame) a position of importance and swap the Greek root mneme ("memory") for the Latin moneo ("to recall", "to warn"). Herodotus notes that this is "preventing the great and wonderful actions of the Greeks and the Barbarians from losing their due meed of Glory. ${ }^{15}$ Art history as it is traditionally understood from Johann Joachim Winckelmann to Erwin Panofsky, gives historic narrative a certain form - a shape of a tame and harmless companion leading its explorer through the long cultural history of centuries and millennia.

The history of art speaks more about the context than about the work of art itself. Instead of discussing Baroque as an expression of a unique state of mind and its kindred philosophical thought, we speak about political events and their identity - allowing us to evaluate Kadriorg Park through the imperial and militant intentions of Peter the Great, and so all the canals and manicured lawns, every architectural ego from the Roman times is merely turned into an illustration and does not exist as a distinct field of interest. It must be said that there is little I have to add to the scholarship on Kadriorg Park in the vein of the "objective history of art". ${ }^{\prime \prime}$

My issue lies elsewhere: besides the social and historical analysis there is the cognitive aspect of art, an angle that transforms the social into personal: being inspired by the spirit of the times and one's own imag-

3 Charles Sanders Peirce, Collected Papers, Vol. 2. eds. Charles Hartshorne, Paul Weiss (Cambridge (Mass.): Harvard University Press, 1932), 308.

4 Michael Leja, "Pierce's Visuality and the Semiotics of Art", A companion to Art Theory, eds. Paul Smith, Carolyn Wilde (Oxford: Blackwell Publishing, 2002), 303.

5 Herodotus, The Histories, I, 1; Cit.: Alain Schnapp, Discovery of the Past. The Origins of Archaeology (London: British Museum Press, 1999), 43.

6 Academic interest towards the Kadriorg Palace began in the nineteenth century. However, the first monograph on the architectural ensemble was published only much later by Mai Lumiste, Kadriorg. Loss ja park (Tallinn: "Valgus", 1988); several articles about the construction history of the Kadriorg Palace have been published by Jüri Kuuskemaa in the Art Museum of Estonia pubications 1977-1991. 
ination, it precedes the birth of a pictorial image. The cognitive aspect of art includes an indefinable "other" that brings forth the ergon within the parergon, enclosing the whole of human sensibility in a creative act; it attunes the sensory perception and cognition, and maybe even more - determined not only as a "sensory phenomenon but [it] involves a free and open-ended engagement of the fundamental resources of the human mind." ${ }^{\prime 7}$ Since Alexander Baumgarten there has been a new source in the literature on the arts: defined as aesthetic category it considers subjective experiences and introspection; it points at the source of arts and offers in the place of conventions an innovation, giving the artistic will (Kunstwollen, as Alois Riegl put it) an expression in an artwork. "The art work opens up in its own way the Being of beings. This opening up, i.e. this deconcealing, i.e. the truth of beings, happens in the work [...] Art is truth setting itself to work." ${ }^{\prime 8}$

Art is pushed into movement by the same fundamental force that operates in music and poetry, even in the case of Winckelmann, the child of the Enlightenment century, we see alongside rationality an emotional side of his character - his melancholy and bitterness of loss that in Davies' words "would also be to recognize his History as a great and exemplary work, for it comes close [...] to finding an objective subject that almost satisfies its subjective object ${ }^{\prime \prime}$, apart from external events emotion leads a scholar towards an inner self and within his critical method, close to the sources of artistic events, opening them layer by layer, announcing themselves as an absolute dimension of our mind, as a philosophical system where "it is the ego which [...] discovers itself as the only apodictically certain being."10

Artist is a demiurge who makes the journey between two eternities possible: he marries the great grandiose with the insignificant and the universal with the particular. In art and through art, creation becomes actuality, hidden capacities in people are unveiled making the subconscious visible and audible in the form of images and sounds, and so art glorifies stone and clay. In this way, artistic event makes the world vis-

7 Jason Gaiger, "The Aesthetics of Kant and Hegel”, A Companion to Art Theory, 129.

8 Martin Heidegger, "The Origin of the Work of Art", Martin Heidegger, Poetry, Language, Thought, trans. by Albert Hofstader (New York: Perennial Classics, 2001), 38.

9 Whitney Davis, "Winckelmann Divided: Mourning the Death of Art History", The Art of Art History: A Critical Anthology, ed. Donald Preziosi (Oxford: Oxford University Press, 1998), 49.

10 Edmund Husserl, The Paris Lectures, trans. and introductory essay by Peter Koestenbaum (Dordrecht: Kluwer Academic Publishers, 1998), 4. 
ible, cities tangible, and turns a landscape into cosmos. "Infine il caraterre più sensibile dell'onnipotenza di Dio è che la nostra immaginazione si prede in questo pensiero. L'uomo, tornato a se stesso, consideri ció che é, in confronto a quanto esiste... intendo dire universo, apprenda a valutare la terra, i regni, le citta, e se stesso nel giusto valore." 11

Eidos is at the source and at the end of all that there is, everything else is written in between. Art is born where chaos borders on order; human being is the interlocutor of truth, his genius lights up the stars in the darkness. The formation of a colourful image that we label our world is aided by the artistic process, and so the Idea finds a form. The criterion of artistic truth has the same ontological basis that has tantalised the human mind from the rise of Greek metaphysics onward. Contemporary humanities originate in the subjective analysis of the objective external world, distinguishing between traditional object-subject schema and deep transcendental layers "where the cognition as the existential vehicle of life, remains geometrically and cosmically linked and positioned."12

Besides the narrative time, equally important is a sense of spatiality - an a priori actuality that we experience through artist's work, always renewing its forms and images though the genius of Zeitgeist; in Martin Jay's words this links vision and the visual memory in a way that "can signify graphic, optical, perceptual, mental or verbal phenomena" and marks the "boundary between the "natural" and the "cultural" in what we call vision." ${ }^{13}$ Written texts and philosophy are part and parcel of art history - in addition to Winckelmann's history there is the aesthetic approach of Alexander Baumgarten. Appreciating and gauging both, we avail ourselves to untried prospects that can provide a fresh understanding in the study of the arts, combining generalized theoretical methods and fact-based specific material. The history of art relies on theoretical ideas to the same degree as on the empirical facts: these ideas - as of today still under-utilised - could not only function as a descriptive backdrop but also as sources for novel methods when dealing with a variety of research issues. In this way art historian has not only an Aristotelian

11 Paolo Portoghesi, Roma barocca (Rome \& Bari: Editori Laterza, 2002), 7.

12 Anna-Teresa Tymieniecka, "Transcendentalism Overturned. From the Absolute Power of Consciousness Until the Forces of Cosmic Architectonics”, The Yearbook of Phenomenological Research, Vol. CVIII, ed. Anna-Teresa Tymieniecka, Analecta Husserliana (Heidelberg, London, New York: Springer Dodrecht, 2011), 3.

13 Martin Jay, Downcast Eyes: The Denigration of Vision in Twentieth-Century French Thought (Berkeley, Los Angeles, London: University of California Press, 1993), 9. 
science at his service but can also employ philosophy: in addition to deduction he can now start with induction and with the Idea that according to Plato determines the existence. Descartes and Leibniz set a new tone and direction for this strand of art history which allows us to discuss not only the transformation of styles but to treat history of art as an expression of the ideas of Descartes, Leibniz, Immanuel Kant, and Hegel through forms and in the world of artefacts.

\section{FROM ESPRIT DE SYSTÈME TO ESPRIT SYSTÈMATIQUE}

Is reality an odd fabrication or an immanent presence of the Truth, asks Descartes and centuries later, we may echo the same question. Who am I - a human being? What are the prime causes that set things in motion? "I am, however, a real thing and really exist; but what thing? I have answered: a thing which thinks [res cogitans]."14 The influence that Descartes had on the scholarly world of the seventeenth century (and even more so of later centuries) is difficult to overestimate. On the one hand Descartes unifies the hitherto unnoticed trends of his time, bringing these to light through his imaginings and his words, influencing sciences and arts both directly and indirectly. On the other hand his confidence and to an extent his self-centeredness determine an epoch that is defined in the history of art as the Baroque. The prerequisite for all that exists is a mind: "both for the conduct of his life and for the conservation of his health and the invention of all the arts ..."15 The complement of life is a fantasy, everything that we dream of and all that we perceive as visual illusions. "At the same time we must at least confess that the things which are represented to us in sleep are like painted representations which can only have been formed as the counterparts of something real and true [...]. For as a matter of fact, painters, even when they study with the greatest skill to represent sirens and satyrs by forms the most strange and extraordinary, cannot give them natures which are entirely new [...]."16

14 René Descartes, "Meditations on the First Philosophy in Which he Existence of God and the Distinction Between Mind and Body are Demonstrated", II, The Philosophical Works of Descartes, vol. I, 152.

15 Descartes, "The Principles of Philosophy", The Philosophical Works of Descartes, vol. I, 203-204.

16 Descartes, "Meditations on the First Philosophy", I, 146. 
The order in Nature is determined by the will of the subject, its strength and beauty. The world appears to us through the mind, which as mathematics convince us does not ensue from mere relations between geometries and shapes, but from of a true and sacred logic of numbers that organises the spatial unity in the Baroque architecture. „For example, when I imagine a triangle, I do not conceive it only as a figure comprehended by three lines, but I also apprehend these three lines as present by the power and inward vision of my mind, and this is what I call imagining. ${ }^{\prime 17}$

Descartes embodied an aspiration that defined his times: to order the world by the rules of systematic thought (esprit de système), deducing facts from a priori axioms ${ }^{18}$ - a system of lines aspiring towards infinity, creating a grand performance for the earth, its landscape and the cosmos, clustering around itself a universe that exists both mentally and in material unity. In this manner the epoch reveals something that the visible can reflect but cannot exhaust nor explain. The artist's " $\mathrm{I}$ " is the source of discussion and judgement, through "I" he expresses the opposites of his character - his judgement and invention (giudizio e invenzione);" first is related to the emerging of critical thought and the second, to the energy that is needed for the birth of an artwork. "The noble painters and sculptors, imitating the first creator, form in their minds also an example of superior beauty and, reflecting on it, improve upon nature. Primitive imitation of nature might suit simple souls and lower classes, but the duty of a true artist is to represent nature not as it appears to us nor as it manifests itself through irrational illusion," ${ }^{\prime 20}$ but as has described by Gian Pietro Bellori: "this Idea, or rather the goddess of painting and sculpture, when the sacred curtains of the lofty genius of a Daedalus or an Apelles are parted, reveals itself to us and descends upon marbles and canvases; originating in nature, it transcends its origins and becomes the original of art; measured by the compass of the

17 Descartes, "Meditations on the First Philosophy", VI, 185.

18 Christian Norberg-Schulz, Spätbarock und Rokoko (Stuttgart: Deutsche Verlags-Anstalt, 1985), 5.

19 Ann Sutherland Harris, Seventeenth-Century Art And Architecture, Second Edition (London: Laurence King Publishing, 2008), xxi.

20 Frederico Zuccari, L'ideade 'pittori, scultori, et arcitetti (Turin, 1607), cit. Mosche Barasch, Theories of Art 1, From Plato to Winckelmann (New York, London: Routledge, 1985), 317. 
intellect, it becomes the measure of the hand; and animated by the imagination of it gives life to the image." ${ }^{21}$

What Nature cannot do on its own, art can. Art helps one to rise above the cynical sentiment about corruption of politics and manners of the times (corruzione dell'éta nostra) by raising the idea up from its footing where it reaches heights where absolute truth prevails - as clarté et distincté. This same sphere where planets move turns in the direction of relativism towards the end of the century, replacing an ordered world model of Copernicus with the elliptic cosmos of Tycho Brahe; due to specific attributes of our mind we are bound to see relations behind numbers; striving towards ethereal fields where we meet several instead of one, and many instead of several centres of energy. A place where the monads as defined by Gottfried Leibniz not only have their place but also a cognitive capacity that fits universal concepts into a system of words, replacing the dualism of mind and matter with the unity of these two principles. Freed from the dictate of absolute power, through infinite number of substances they create new relationships and by doing this - new cosmoses. In fantasies of artists of the Baroque age, the world is a mirror hall with an infinite number of mirrors and the mirrored images reflect infinity in thousand shattered pieces.

Leibniz' division, a system where everything imaginable is split into simple and composite substances, or collection of monads, summarises the idea of a grand performance "where there is a simple substance there is life and the world's being full of such substances means that the whole of nature is full of life."22 Over time, the system of mind (esprit de systéme) becomes a systematic mind (esprit systématique), as described by D'Alembert in the Encyclopédie, that replaces the belief in the world as a unified system that could be grasped with the help of a corpus of ideas and their corresponding symbols. Leibniz' principe vitale reverberates equally in nature and in architecture.

21 Giovan Pietro Bellori, The Lives of The Modern Painters, Sculptors and Architects, A New Translation and Critical Edition, trans. by Alice Sedgwick Wohl (Cambridge, New York: Cambridge University Press, 2010), 57.

22 Gottfried Wilhelm Leibniz, Principles of Nature and Grace Based on Reason, http://www.earlymoderntexts.com/pdf/leibprin.pdf (accessed 10.11 2013), 1. 


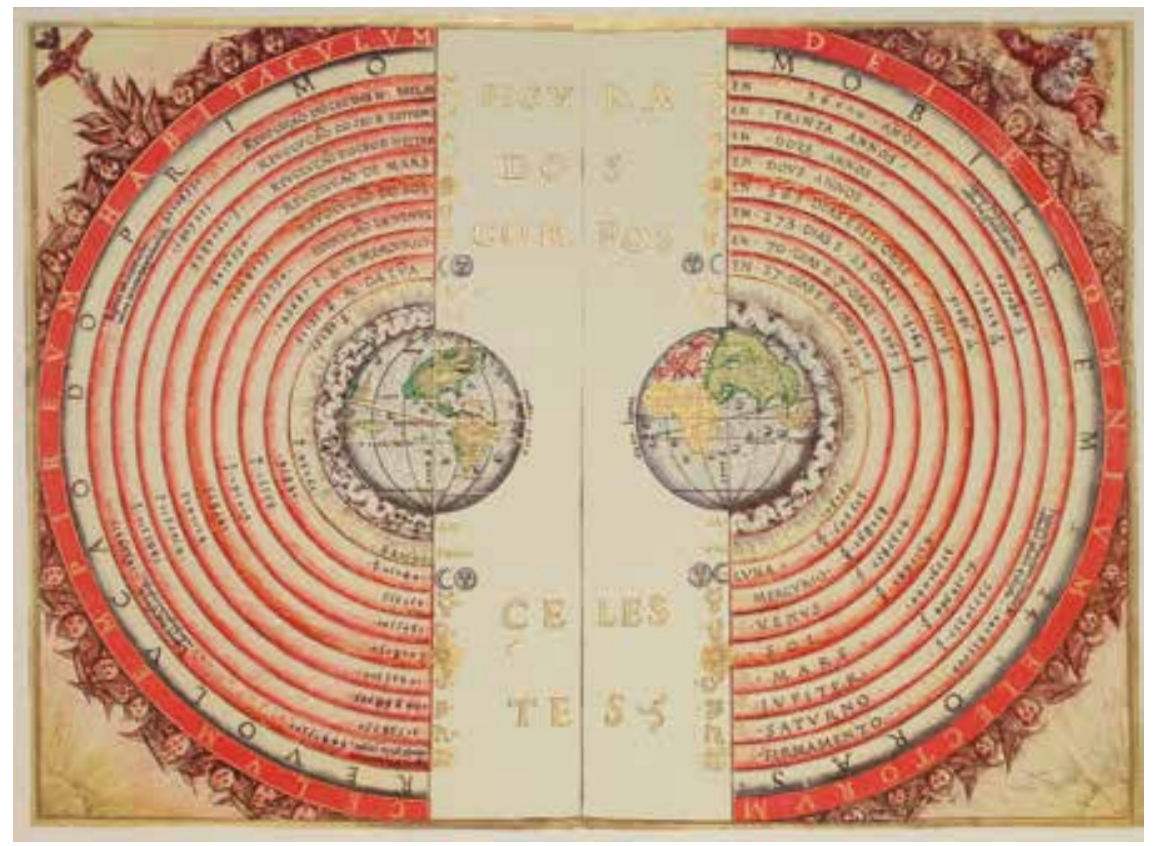

Fig. 1. The Ptolemaic geocentric model of the universe, devised by the Greek scientist Claudius Ptolemy, had everything revolving around Earth.

\section{FROM ILLUSION TO IMAGO}

The Baroque cosmos is a unified whole but it is also fractured into minuscule pieces that through the centripetal force form a mathematically describable system: a universe that is compact and extended into infinity along its axis, its central idea pulling along ever new cosmoses and geographies. Baroque architecture does not spring from the study of nature (although it is often discussed), but rather from the application of nature, expressing the will of a mind that besides gravity brings up a multitude of ideas and their co-existence in nature. "Construction is enjoyment (Lust) whatever it may cost me", declares Balthasar Neumann. ${ }^{23}$

"Baroque is the ultimate of the bizarre; it is the ridiculous carried to extremes. Borromini went delirious, but Guarini, Pozzi and Marchione went "baroque"'", writes Francesco Milizia in his Dizionario delle belle arti

23 Wilfried Hansmann, Baukunst des Barock: Form. Funktion. Sinngehalt (Cologne: Du Mont, 1978), 6 . 




Fig. 2. The Copernican Planisphere, illustrated in 1661 by Andreas Cellarius

del disegno (1797) ${ }^{24}$, and labels Baroque as a period of decline in comparison to the Classic revival of the following period. In the minds of Baroque critics, it continues the traditions of dark ages that already the" antischolastic writers of the sixteenth century found particularly ridiculous. ${ }^{25}$ Contro il barocco (a term used in Italian art historical scholarship) ${ }^{26}$ deprives Baroque from its flesh and blood, its "di far apparire di carne le sue figure", 27 taking away all that saw world as a continuous and indis-

24 Henry A. Millon, The Triumph of the Baroque. Architecture in Europe 1600-1750 (London: Thames and Hudson, 1999), 23.

25 Julius S. Held, Donald Posner, 17th and 18th Century Art, Baroque Painting. Sculpture. Architecture (Englewood Cliffs, N. J: Prentice-Hall, Inc \& New York: Harry N. Abrams, Inc., 1972), 11.

26 See Contro il barocco. Aprrendistato a Romae practicadell'archittettura civile in Italia1780 1820, catalogo della mostra, eds. Angela Cipriani, Gian Paolo Consoli, Susanna Pasquali (Rome: Campisano Editore, 2007).

27 Charles Avery, Bernini. Genius of the Baroque (London: Thames and Hudson, 2006), 265. 


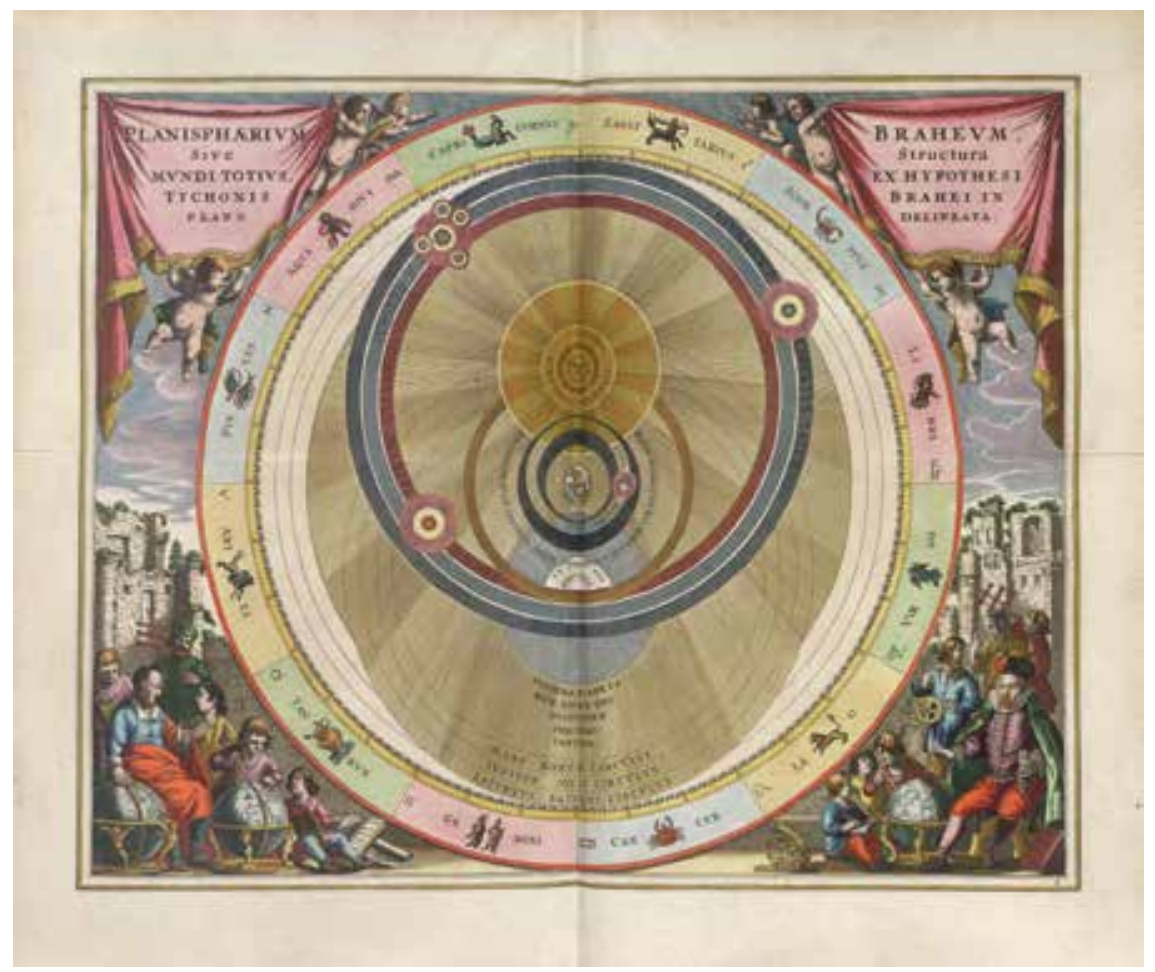

Fig. 3. Tycho Brahe's System of Planetary Orbits, from The Celestial Atlas, or The Harmony of the Universe by Andreas Cellarius

cernibly vast space "in which each molding could become, so to speak, sensitive to the others." 28

Baroque is comprehensible only insofar as its significance in the sphere of ideas is understood, bonding cogito with ego and its dreamlike projection of transcendence. Architecture, nature and landscapes merge and aspire towards cosmic heights, giving birth to new cosmoses where genius of the Zeitgeist with his conductor's baton arranges views, axes and perspectives in nature, invading ever new cascades, ponds and pools all the way to the row of poplars on the horizon, and making them all reflect on the grand Parterre de Latone. The difference in arrangement found in Bernini and Claude Perrault, his competitor, in relation to the east façade of the Louvre, does not manifest so much in the principles but more so in the reflections of ideas that are expressed in the décor,

28 Paolo Portoghesi, "The Baroque and Rococo", The Triumph of the Baroque, Architecture in Europe 1600-1750, ed. by Henry A. Millon (London: Thames and Hudson, 1999), 43. 
the dialogue between buon gusto and bon goût, allowing the Italian and French preferences to find their own arguments and independent forms of visual communication. The potency of Baroque lies in its self-confidence, even if dinted by the polemic of the ancients and the moderns (la querelle des Anciens et Modernes), the movement does not lose strength before its constructed world has expanded to an inconceivable size.

The closer to the turn of the century, the more fractured and diverse becomes the general outlook that gives scope to ideas. Freed from the mental model of a universe inherited from Renaissance and constructed by a single will, art once again faces a choice. It can continue its trotted path that describes universe in its infinite variety through rhyme and rhythm, summation and subtraction; or to diverge from a single canon, from the "positive beauty", and engage with values that can be classified as "arbitrary". "So in the art of building, different rules are determined by the different intentions [...] [these rules] together with their appropriate ornaments are what give rise to the different architectural orders, whose characters, defined by variations in ornament, are what distinguish them most visibly but whose most essential differences consist in the relative size of their constituent parts." ${ }^{29}$

The idea of always measuring universe from the same point of authority is increasingly called into doubt. The growing sense of conflict between rationality and emotions elevates art to the rank of sciences but at the price of creating a discord and an escape to the unknown; to a place where in Late Baroque, the Rococo, aesthetics preach desire in the rhetoric of virgin forests. Europe faces great changes at the time when Peter I cuts a "window to Europe". "La stessa cultura che si batte per le libertà sul piano politico, in campo artistico predica il ritorno al dogmatismo classico e le liquidazione senza distinzioni di una eredità che, nella sua fase più vitale, avera già recepito l'insegnamento delle nuove metodologie scientifiche e sperimentali, aprendo la strada a una concezione dell attività artistica, come ricera aperta e infinita, non critallizabile nell assoluto, nè scindibile dal divenire storico et illusione." ${ }^{\prime 30}$

29 Claude Perrault, "From Ordonnance for the Five Kinds of Columns after the Method of the Ancients" (1683), Architectural Theory. Volume 1. An Anthology from Vitruvius to 1870, ed. Harry Francis Mallgrave (Malden, MA: Blackwell Publishing, 2009), 78.

30 Portoghesi, Roma barocca, 1. 




Fig. 4. Kadriorg in snow, photo by Juhan Maiste

\section{PALACE BY THE SEA}

The greatest minds are capable of the greatest vices as well as of the greatest virtues

René Descartes ${ }^{31}$

What has all this to do with Peter the Great's palace by the sea, set in an area populated by summer mansions of a hanseatic city; a place that from times immemorial has offered citizens an opportunity to come outside of the town walls into the nature? But that much. Kadriorg is a political manifest supplemented by an artistic ambition. For the Kadriorg Palace, the czar chooses Italian architects as he had done for the palaces built in the Petersburg region. He chooses Italians because they hold most authority - their footprints in tutoring the aristocratic elite lead back to the era of François I. The selection functions rhetorically as a device stressing the symbiosis of the intellectual elite and the state

31 René Descartes, “Discourse on Method”, 82. 
power while building a new Rome - the realisation of the Third Rome. In the first summer palace Peter the Great he had built in the Flemish style his bust is crowned with laurel. Building a summer residence for his wife Catherine, in the spirit of Niccoló Machiavelli's Il principe the ego manifests itself in a new Utopia - the building of a Città del Sole..$^{32}$

It is as though the sun had set in the sea. Visions and visionary truth create a dreamlike setting where in the footsteps of titans, Olympian gods clamber onto the stage and turn stone into gold. Their envoy in this faraway, peripheral context is Niccoló Michetti, a man who arrives to Tallinn but is born in Rome and to whom the gates of caput mundi are open. ${ }^{33}$ Michetti's magnum opus - the Cathedral of St Peter the Apostle in Zagarolo, astonishes the viewer even today with its Baroque explosive energy as well as its grandiosity. In comparison to Michetti's palaces in Russia (including Estonia), it has retained not only the outer form but also the inner harmony of Baroque. ${ }^{34}$

An ambassador from another temporal space, Michetti brings a condensed metropolitan thought to the periphery, like a star that is drifted from its path. Within the logic of architecture, the palace and its surrounding park are a point of departure for the praise for geometry and laws of perspective; Ivar-Kristjan Hein describes its form as Golden section; the converging lines of the park extend up to the Mirage pond and its cascade; its central point approximates the centre of the main axis of the palace, a choice that can be interpreted as a praise of the lord of the construction and his mission. ${ }^{35}$ Quite naturally, this brings to mind Descartes: "For example, when I imagine a triangle, I do not conceive it only as a figure comprehended by three lines, but I also apprehend these three lines as present by the power and inward vision of my mind, and

32 Robert Stalla, "Franceso Borrominis architektonisches Werk im politischen, kulturellen und wissenschaftlichen Kontext der römischen Seicento", Borromini. Architekt im barocken Rom, exhibition catalogue, eds. Richard Bösel, Christoph Luitpold Frommel (Milan: Electa, 2000), 31.

33 Niccoló Michetti, born 1675 in Rome, joined the Carlo Fontana studio in 1700, participated in the construction of Ospizio di San Michele. As best known amongst his independent works stands out Zagarolo Saint Peter's Dome Church. In Russia Michetti was commissioned the planning of Strelna Palace ensemble and the Peterhof cascades and fountaines. John Pinto, Niccoló Michetti, architetto romano, presentation at the conference "Niccoló Michetti (1675(?)-1758). Rooma-Tallinn-Peterburi", Kadriorg Art Museum, 5.6. 2009.

34 Gianfranco Spagnesi, Niccoló Michetti - Times and Context, lectures in Kadriorg (2000) and Zagarolo (2002) by the author.

35 Ivar Kristjan Hein, Kersti Lootus, "Kadriorg. Proportsioon ja geomeetria Barokses aiaruumis”, Park on paradiis looduses ja kunstis, eds. Mart Külvik, Juhan Maiste (Tartu: Eesti Maaülikool, 2009), 161. 


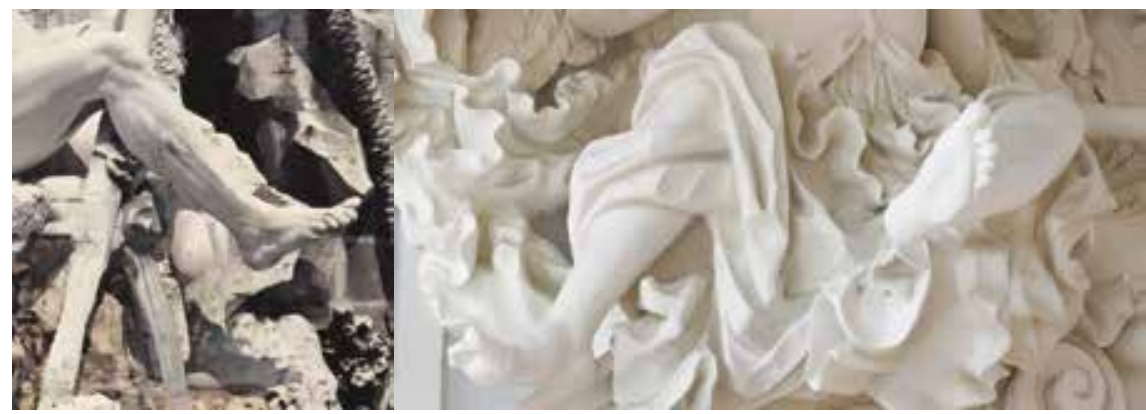

Fig. 5. The feet of Nile by Gianlorenzo Bernini
Fig. 6. The feet of Geni of fame by Niccoló Michetti

this is what I call imagining." 36 Thus the construction of a new cosmos can involve a secret agenda of the world's powerful.

Space originates in a fixed point. In Rome, Michetti was one of Carlo Fontana's students and took part in his teacher's construction work at the Santa Cecilia Cloister Convent, acquiring from his experience a habit of the times to see the world as if it was springing from an active and explosive source. Likewise, we come to see Kadriorg as a monad that is moved by Leibniz' principe vitale, as a lively concept of a universal cosmos supported by empirical, natural sciences. ${ }^{37}$ Thus Kadriorg Palace allows itself to be read as if it were a substantial book, placed on the shelves of a library of Modern Age philosophy. In essence, the palace on the outskirts of the old hanseatic city belongs to a transition period, to a time when singular idea is transformed into a multitude, a case of "more means the sum of its parts"; expressing Guarini's "Placita Philosophica" as a method of ars combinatoria, the pulsating energy and swinging rhythm that brings forth an openness instead of the previous closedness, undefined relations instead of clear delineations, and a "pluralistic" space of many viewpoints and instead of a space of just one denominator. ${ }^{38}$

36 Descartes, "Meditations on the First Philosophy”, VI, 185.

37 Arnolf Nesselrath, Schiefrund, „'und sie bewegt sich doch' Einleitende Bemerkungen zum 'Barock im Vatikan'“, Kunst und Kultur im Rom der Päpste. 1572-1676, 25. November 2005 bis 19. März 2006. Kunst und Ausstellungshalle der Bundesrepublik Deutschland (Bonn, 2006), 31.

38 Norberg-Schulz, Spätbarock und Rokoko, 10. 


\section{RUSSIAN RULE AND ROMAN LIGHT}

To tell you the truth, once this is ready it will be a marvellous thing. Peter $\mathrm{I}^{39}$

Jüri Kuuskemaa has noted that the first sketch of Kadriorg was made by Peter the Great himself. ${ }^{40}$ As Peter was a multi-talented and travelled man, this fact would not contradict the architectural idea and its logic in any way. During the Baroque period, a patron becomes a client - a lord and master giving orders, directions, and explications; someone whose taste requires consideration. To measure the land, make a few strokes on the drafting paper, place the vestibule and hall on the axis, in the absolute centre, create the focal point for the whole system. Time passed quickly at the drawing desk while drafting the project. The extent to which a professional architect could consider these ideas is a different matter. Kadriorg is a fragment of the Baroque cosmos, foreign, at least initially, reflecting the cosmopolitan tendencies of its era, yet reserving its close ties with Rome.

Compared to larger building projects by Michetti in Russia - Peterhof cascades and fountains and Strelna Palace - an important dissimilarity comes into view. Of the two building types of high aristocracy that were developed already during the Renaissance period and continued in principle until the eighteenth century - the palace and the villa, Kadriorg represents a nature-bound summer residence. ${ }^{41}$ Instead of the palas originating in imperial Rome and the Italian palazzo of the patriciate - the class of buildings that have an official and representative function impelling a fortress-like closed composition and corresponding plan and shape - Michetti is guided by a free composition that harmonises with landscape. Besides the rhetorical presentability of the Latin culture, another aspect is important - leisure and emancipation from the court. This shapes a philosophy that allows an expression of the ego in its polar opposite, in the silence and peace of a countryside life. „The basic program of the villa has remained unchanged for more than two

39 Pis'ma russkih gosudarej (Moscow, 1861), 88-89, cit. Jüri Kuuskemaa, "Lossi- ja pargiansambli rajamine. Kadriorg 18. sajandil", Kadriorg. Lossi lugu / Palace's story, eds. Jüri Kuuskemaa, Aleksandra Murre, Mart Kalm, Kadi Polli (Tallinn: Kadrioru Kunstimuuseum: 2010), 27.

40 Kuuskemaa, „Lossi- ja pargiansambli rajamine”, 30.

41 Fabio Benzi, „Paläste und Villen Roms von der Renaissance bis zum Spätbaeock“, Caroline Vincenti, Fabio Benzi, Römische Paläste (Munich: Orbis Verlag, 2003), 7. 


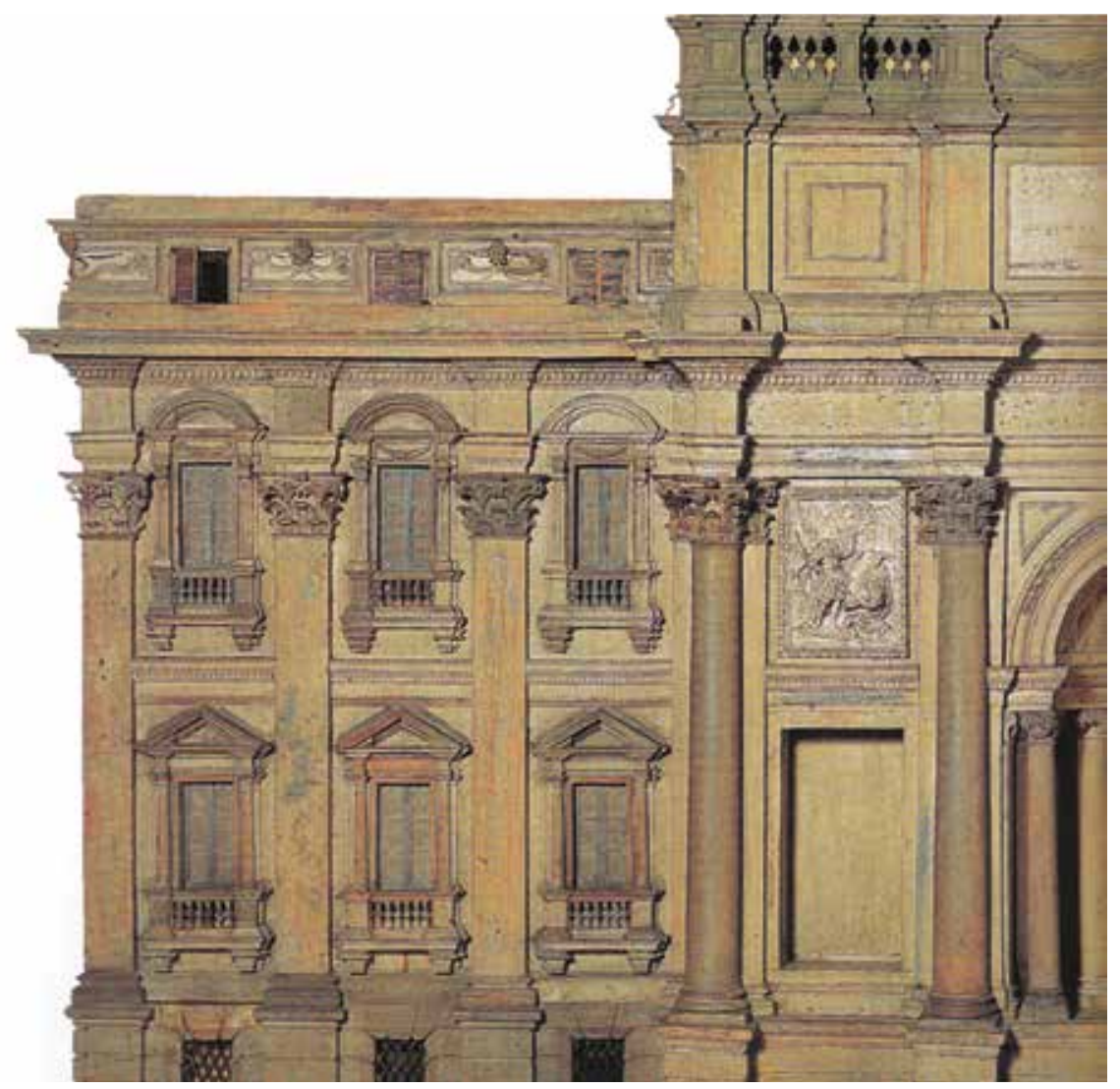

Fig. 7. Niccoló Salvi, wooden model for the Trevi Fountain

thousand years since it was first fixed by the patricians of ancient Rome [...] because it fills a need that never alters, a need which, it is not material but psychological and ideological, is not material to the influences of evolving societies and technologies. The villa accommodates a fantasy which is imperious to reality. ${ }^{\prime 42}$

These are not only cases of formal and architectural differences but dissimilarities originate already in the minds behind them. Villa suburbana and villa maritima are classifications that in the case of Kadriorg are as important as is the palatial representative character. From the very start, Kadriorg was not planned an excessively grandiose a place; besides the court etiquette there is room left for the wilderness - an oak

42 James S. Ackermann, The Villa. Formand Ideology of Country Houses (London: Thames and Hudson, 1990), 9. 

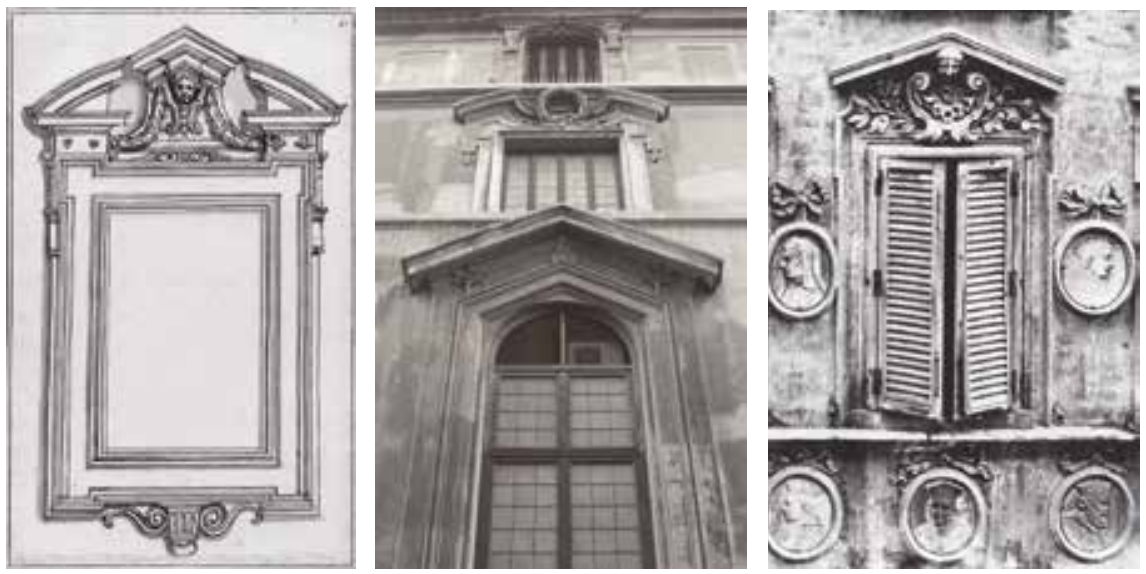

Fig. 8.-10. The windows of Rome. Drawing after Pietro Da Cortona, Collegio di Propaganda Fide - Francesco Borromini, Casa dei ritratti in via del Governo Vecchio by Domenico Gregorini

grove and horse chestnut gardens, hayfields scattered with boulders that extend to the sea. The relation between palaces and nature must be stressed not only in case of Kadriorg but also other residential gardens of Peter I. The association with the nature may be even more than Michetti, himself schooled in Rome, consciously aspired for. Kadriorg reflects the tendencies that shaped the intellectual world in the early eighteenth century and soon led to the dominance of the informal garden style first in England and thereafter in Holland. „Our drift is a noble, princely and universal Elysium, capable of all the amenities that can naturally be introduced into Gardens of Pleasure, and such as may stand in competition with all the designs and stories of this nature, either of ancient or modern times. ${ }^{.43}$

The freedom was limited by thought: from the common central point a geometrical structure was planned, foregrounding the rooms that were planned according to the centralising principle of Baroque architecture - hence a ballroom extends through the ground floor and the first floor; underneath it as Mai Lumiste has described it, a vestibule was placed, in this case an unusually intimate and undersized one, and in the manner of the Italian casino, for the consideration of an overall symmetry placed

43 Michael Leslie, „Bringing Ingenuity into Fashion: The „Elysium Britannicum“ and the Reformation of Husbandry“, John Eveyn's Elysium Britannicum“ and European Gardening, eds. Therese O’Malley, Joachim Wolschke-Bulmahn (Washington D.C.: Dumbarton Oaks Research Libray and Collection, 1993), 133. 


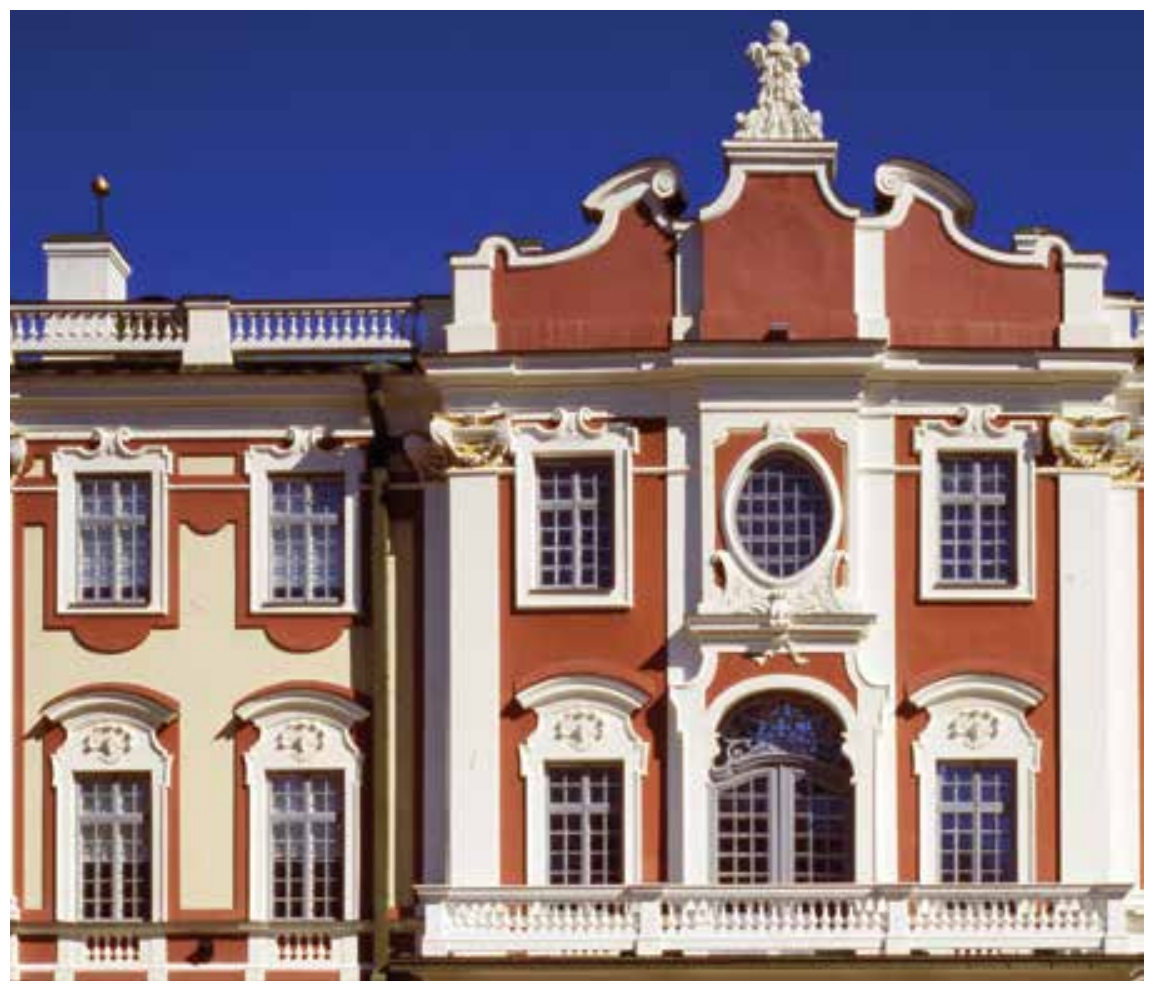

Fig. 11. Kadriorg Palace. Fragment of the fassade. Art Museum of Estonia photo archive

off-centre. ${ }^{44}$ It seems probable that Michetti's drawings were detailed and had masterful décor smothered in lacework that, together with water foam on the cascades, highlighted the buon gusto as naturalised in the Baroque architecture - covered by a veil of dreams.

On the façades of Kadriorg, a plastic style that characterised palaces of Rome until mid eighteenth century (Palazzo Pichini (1710) and Palazzo Doria (1731-1733)) survives. The plastic form is joint by Mannerist heritage of Giulio Romano (Palazzo Te in Mantova and Villa Lante in Rome): a free and playful mode still alive in the eighteenth century, introduced by the androne (vestibule) and the cortile (front yard), and thereafter set free in the cavalcade of Piano Nobile décor, hiding its opulence within the overall logic of the building's architecture. The architectural composition of the building in whole as well as the interior design rests upon a

44 Lumiste, Kadriorg. Loss ja park, 29. 
continuity of attractions, surprising its visitor with a multitude of ideas and an artistic superabundance - every room has its own life, its own character in the connected row of enfilades. In Michetti's oeuvre an irresistible desire for dramatic effects endures, in the same way as the passion of Borromini and Bernini persists in the late seventeenth century and early eighteenth century palaces built in Rome, Naples, and Turin.

Michetti's architectural credo lies in Rome, in all that surrounded him on the streets of the eternal city as well as at the studio of Carlo Fontana. History does not appear to him through mediators but from the primary sources, outlining a trajectory from Antique to Renaissance and Baroque, with geniuses of their times - from Alberti to Michelangelo and Carlo Maderno - as its milestones. Thus the prototypes for Kadriorg and other palaces planned by Michetti on the shores of the Baltic Sea are emblematic of the Roman architecture: Palazzo Senatorio planned by Giacomo della Porta and Girolamo Rainaldi, Villa Medici and Palazzo Montecitorio initiated by Bernini and finished by his student Carlo Fontana. Michetti's angels and sculptures on the roof balustrade signal the presence of Rome. His terrace gardens enable us to see a penchant for Italian gardens with their attractive, abruptly rising planes.

One metaphor for Rome - continuity - lives on in the works of Michetti because it was his inner conviction and, so to say, in his blood. Albeit subdued and fractured by the spirit of its times - on the one hand by the historical synthesis and on the other, formal differentiation, ${ }^{45}$ a glamorous idea about an infinite number of energy sources takes the place of a unified concept of cogito. In this context the contradiction between the real and the visionary retreats quietly into the melancholic stillness of the Classics, replacing grandezza with the metaphors of grandioso and its corollary, eccelente. The change is to some extent influenced by the new wave of French architectural innovation, initiated by Vaux-le-Vicomte and Versaille, it spreads to Italy in the form of innumerable architectural treatises and reference books and influencing the park design of the early eighteenth century in the vast area from Naples to Milan. Instead of noble simplicité we see complex and multi-layered ensembles where character (caractère) is on the foreground with its essential pull for the individual and the nuanced, allowing differentiation between parts of

45 Norberg-Schulz, Spätbarock und Rokoko, 140. 
the ensemble, stressing the uniqueness of design and its connection to genius loci.

Evaluating Kadriorg Park in the temporal and spatial context of its era, we face a decision. First of all - Kadriorg is more classical than we can imagine. But classical in the baroque sense, what assembles the parade of the 16.-17. century creators from Michelangelo to Bernini, and Borromini to Pietro da Cortona, bringing together the emotional power of Veneto and Lombardy and Rome. "Both Bernini and Borromini frequently and fervently declared themselves devotees of the art of ancients." Pietro da Cortona and Carlo Fontana followed their ideas. Guglielmo Cortese, Ciro Ferri, Lazzaro Baldi, and "our man" - Niccoló Michetti followed famous examples and remained true to the Roman tradition until the early years of the eighteenth century. The baroque cosmos of Italy is not only unique but also united as described by Leibniz, where the principles give birth to monadic stars.

For the time of Michetti, the idea of universal art had found a new cosmopolitan expression, synthesizing the Italian traditional garden giardino, with the principles of the French new formal garden - jardin à la francaise. In the time frame of a few years and a few decades, it gains recognition in Europe, because it was all-in-all one and the same cultural space. It was the same Europe where the ideas of André Le Nôtre become prevalent both through the example of the court of the Sun King as through Antoine-Joseph Dezallier d'Argenville's architectural treatise (1709) introducing the principles of French garden architecture. ${ }^{47}$ The author of the illustrations for the publication was Jean-Baptiste Alexandre Le Blond, a man who, after being invited to Russia, was made responsible for Saint Petersburg and its first city plans.

Kadriorg was Michetti's first undertaking in Russia. In addition to a possibility that Peter personally advised him on the design of Kadriorg, it is only reasonable to suggest that as a gifted and efficient man, Michetti made himself familiar with the principles already at work in Petersburg and blended these ideas with his own Roman grounding, thus justifying his commissions in Russia. In his works Michetti was able to combine perspectives with the picturesque - thus offering a unique symbiosis

46 Jörg Martin Merz, Pietro da Cortona and Roman Baroque Architecture (New Haven and London: Yale University Press, 2008), 255.

47 Nicole Garnier-Pelle, André Le Nôtre and the Gardens at Chantilly in the 17th and 18th Century (Domaine de Chantilly - musée Condé \& Somogy éditions d'Art, 2013), 19. 
of the First Rome and the Third Rome. From Kadriorg, Michetti moved to Strelna where he took over the construction of the residence that had already began according to Le Blond's drawings. ${ }^{48}$ As he had done before, he prepared plans for the grand stone palace, for the canals as well as the upper terrace. Relying on the dominant style of his times - the French approach - he nevertheless continued on his own authentic path - designing the palace in Italian style, so truthfully that once completed, it could have confused a guest about his whereabouts. Taking into consideration both what had been offered by the nature as well as the wishes of the emperor, Strelna is in its architectural articulation and in its décor as Romanesque as possible.

Michetti's architecture in a new city and new country is an embodiment of a cosmos born out of the last breath of the Baroque in the eternal city; opening to us not one singular viewpoint as Louis XIV had dreamt, but a combination of infinitely branching sources of energy and viewpoints, becoming a place where the smallest planet has its own role and a starry path. The models for Kadriorg, Strelna and other similar works are the sixteenth and seventeenth century masterpieces of Rome - from Casino dell'Aurora to Villa Pamphili and Villa Borghese. ${ }^{49}$ When we look at Kadriorg today we should see it through the eye of the mind and memory, so that instead of the naked view we would be able to integrate an idea and its explosive energy source in our mind. When Michetti turned back home after the death of Peter I, he presented the project plans of Strelna Palace ensemble to be admitted a member of the Academia di San Luca. ${ }^{50}$ The plans are preserved at the Academy until today. The world around Rome had spread further.

48 Pamyatniki arhitektury prigorodov Leningrada (Leningrad: Stroiizdar, 1983), 581.

49 See more: Vincenti, Benzi, Römische Paläste.

50 Angela Cipriani, Niccoló Michetti e Academia di san Luca, presentation at the conference "Niccoló Michetti (1675(?)-1758). Rooma-Tallinn-Peterburi”, Kadriorg Art Museum, 5.6.2009. 
Juhan Maiste: Kadriorg: the Spirit of Baroque and the Will of Genius. A Palace on the Edge of the Third Rome

Keywords: Baroque, genius, cogito discourse, Cosmopolitan Influence of Rome, Baltic genius loci

\section{SUMMARY:}

The article examines the Kadriorg Palace near Tallinn, Estonia, planned by Rome-born architect Niccoló Michetti. Instead of the factual art history the emphasis is put on the history of ideas. The ideas explored are appropriated from René Descartes and Gottfried Wilhelm Leibniz, thinkers who embody the philosophical thought of the Baroque era. In this fashion the intellectual substance of art is combined with philosophical ideas driven by their metaphysical causes. The objective of the article is not to add new narratives to the existing histories but to attempt instead an escape from the enchanting state of magic of the parergon towards a genesis of one's own cosmos, geometry and architecture.

The closest connection to the Kadriorg architectural ensemble is found in the distinctive attributes of the Italian architecture that at the turn of the eighteenth century replaced earlier cathartic and dramatic approaches, instead emphasising finer arrangements that favoured classical harmony, and as a result new possibilities of diversions and quests for alternatives were created. In place of the authoritarian rule of power, an independent and creative will - a fundamentally new idea of its time - emerged through progressive architecture, using fantastic and visionary approach to prepare for changes in the architectural composition as well as in its plastics and décor. Kadriorg, like everything else Michetti designed, belongs to a period of transition, a time when tiredness of the earlier rhetorical expressivity has not yet completely waned but survives in the dynamics of the décor as well as in the exacting principles of French formal gardens. In Kadriorg we see a multitude of ideas instead of a single concept, an interaction and symbiosis between various fields of influence, accepting in addition to the ceremonially official the presence of wilderness - in this way calling attention to the otium and the genius loci. 
CV:

Juhan Maiste is professor and Head of Department of Art History at the University of Tartu. As a prolific writer he has authored a large number of of monographs and articles on architecture, classicism, cultural heritage, the philosophy and poetics of art history. Also among his scholarly interests have been Estonian and Livonian manour architecture, the phenomenon of park landscapes as well as the work of Johann Wilhelm Krause. In addition to teaching and research, professor Maiste curates the publication of the Baltic Journal of Art History. 